\title{
Human Security Perspective from Several Countries Across the World and Recommendations for Vietnam
}

\author{
Nguyen Thi Thu Thuy ${ }^{1}$ \\ ${ }^{1}$ Institute of Women Studies, Vietnam Women's Academy, Vietnam \\ Correspondence: Nguyen Thi Thu Thuy. E-mail: thuyhpvn19@gmail.com
}

Received: November 12, 2021

Accepted: December 23, 2021

Online Published: Janaury 31, 2022

doi:10.5539/ass.v18n2p25

URL: https://doi.org/10.5539/ass.v18n2p25

\begin{abstract}
Human security is being concerned as a global issue. Human security, which has gone from the theoretical to the practical, has been attracted by national agendas, scientists, international organizations, politicians, policymakers. In the current new context, human life has to face many unpredictable threats and dangers such as the Covid-19 pandemic, natural disasters, environmental pollution, violence, job crisis, etc. This article focuses on analyzing and evaluating approaches to human security in the world through the approaches of international organizations and scientists in different countries around the world. Thereby, learned lessons making recommendations to apply for studying human security in Vietnam contemporary.
\end{abstract}

Keywords: human security, human security approach, Vietnam

\section{Introduction}

Since the cold war has had ended yet, the world has had many changes and fluctuations, the trend of peace, cooperation, and integration has grown stronger and more developed. However, together with the process of globalization and international integration, people are facing many challenges and threats. It also means countries in the world are facing serious challenges due to the dangerous threats to human security. There are not many nations that will have real security if its people are always feeling fear, insecurity, and disease.

Human security, which is seen as a global issue, is closely related to the 2030 Agenda security. Human security's people-centered approach is an essential tool to realize the core ambition of the 2030 Agenda - that is to leave no one behind (UNDP, 2019). The concepts of human security have gone from theoretical to practical. Strengthening human security will break down the vicious circle that has existed for many decades (UNFPA, 2020). Therefore, it has been paid attention and enormously increase in interest by many governments, the broader community, policymakers, scholars.

Human security studies always have different perspectives and approaches depending on the context and characteristics of each country and region. On the one hand, theories of human security in practice are increasingly accepted in many countries around the world, making an important contribution to ensuring human rights and sustainable national development. On the other hand, human securities still have overlap between the dimensions of human securities. Thus, if the approach to human security is correct, suitable to the specific conditions of each country and region, it will promote and gather the strength of the international community, states, and individuals in dealing with threats and challenges.

However, there is the fact no matter how strong the country is, that country cannot stand alone to confront the threat to human security. In addition, within each nation which comprises potential factors such as instability, internal and external conflicts. As a result, those experiences and cooperation between countries in solving the problem of human security are very necessary and help people gain "freedom from the fear, freedom from the want" (UNDP, 1994).

Vietnam is currently facing many challenges and is increasingly unpredictable due to the impact of the financial crisis, natural disasters, corruption, especially the serious impact of a Covid-19 pandemic to human security. Therefore, Vietnam needs new and innovative approaches to strengthen researches on human security. In doing so, the analysis of approaches and studies on Human security from other countries in the world in order to make recommendations for Vietnam that is extremely important in the current context. 


\section{International Organization Approaches to Human Security}

\subsection{The Report on Human Development of UNDP}

The concept of human security was presented for the first time in the 1994 Report of UNDP. The report defined human security as "security from threats such as hunger, disease, and oppression; protection from unexpected and damaging disruptions in daily life whether at work, at home or in communities". The report that, if the nature of human development is to enhance capabilities and widen opportunities for all individuals, then human security implies ensuring "freedom from deprivation" and "freedom from fear" (UNDP, 1994).

The report identified the following four essential characteristics of human security: i) Human security is a universal concern. It is relevant to people everywhere, in rich nations and poor; ii) The components of human security are interdependent; iii) Human security is easier to ensure through early prevention than later intervention. It is less costly to meet these threats upstream than downstream; iv) Human security is people-centered. It is concerned with how people live and breathe in a society, how freely they exercise their many choices, how much access they have to market and social opportunities - and whether they live in conflict or in peace.

The structure of human security includes seven basic dimensions as follows: personal security (avoidance of violence and intimidation), environmental security (access to water, soil, air, and water clean), economic security (guaranteeing basic income), political security (guaranteeing freedom and basic human rights), community security (preserving cultural identity), health security (relative avoidance of disease), and food security (access to food) (UNDP, 1994, p. 23)

\subsection{The World Banks and Voices of the Poor}

The World Bank has contributed to the human security debate, but the World Bank applied concepts of security more than human security. In the 2001 report on poverty, the World Bank outlined three pillars in reducing poverty such as facilitating empowerment, promoting security, and enhancing opportunities. The World Bank also believes that economic and human security are prerequisites for sustainable development (World Bank, 2001).

The World Bank's World Development Report 2001/1 on Poverty identifies three pillars of poverty reduction efforts: facilitating empowerment, enhancing security, and promoting opportunities. The "security" pillar is described as follows: "Reducing vulnerability - to economic shocks, natural disasters, ill-health, disability, and personal violence - is an intrinsic part of enhancing well-being and encourages investment in human capital and in higher-risk, higher-return activities." In substance, the report uses security to refer not narrowly to economic security for vulnerable populations, but also to conflict prevention and resolution (World Bank, 2001/1).

The significant contribution of this report from the human security perspective is the organic fusion of hitherto disparate areas of study: risks and vulnerabilities (including natural disasters, health threats, violence, safety nets, economic, political, and environmental risks), risk management strategies (prevention, mitigation, coping), and studies that recognize distinct strategies depending upon the size and nature of the affected community from the level of the individual household to the international community and planet. As the "security" emphasis seems to have arisen independently of the human security literature (and their associated interest in resource mobilization), it underscores the coherence and relevance of this "poverty-conflict" nexus of concerns. The World Bank also believes that economic and human security are prerequisites for sustainable development (Word Bank, 2001)

\subsection{Human Security Approaches from Scholars in the World}

The "1994 Human Development Report" of UNDP has inspired to scholars carrying out researches on security such as "Human Security: A Case Analysis Framework in Transition and conflict", Arie Sam and Jennifer Leaning (2001),; "Human Security: A Transformation or Just a Repetition" (Paris Roland, 2001); "Securing Humanity - Situating the Humanity the Human Security discourse" Gasper Des (2004); Human Security: from Paradigm Sift to Operationalisation, (Glasius Marlies, 2008) ... However, those concepts and dimensions of human security that remain fragmentary and arbitrary. For example, Gary King and Christopher Murray (2001) in the study "Rethinking Human Security" identified the main scope of human security including health, education, income integration, political freedom, and democracy. As result, researchers proposed a way to calculate the human security index and determine the critical level for each area under which the individual is considered insecure. Another researcher, Caroline Thomas (2000) supposed human security is the fulfillment of basic material needs, dignity and democracy. Fen Hampson (2002) argued that the components of human security are physical safety, fundamental freedoms, basic economic needs.

There are some studies of human security that focus on specific country such as the study of Shahrbanou 
Tadjbakhsh (2014) in Norway, which mentioned that the concept of human security was applied for their foreign policy as well as social aid since after the 1994 UNDP report. The author also pointed out the case of Norway not only pursues human security goals at the global level but also the leading country that applied concepts of human security as the national goal through internal policies review. Therefore, the human securities program in Norway is a vehicle for the government to address human rights issues at the international level, enhancing the economic and commercial interests of the country. It can be said that Norway is a good example to encourage other countries regarding policies of Human security.

Author Elena (2005) focuses that human security in Japan which must be placed in the historical context of the country is viewed in a multidimensional context, as well as reflect priority policies in specific contexts. The author points out the Japan emphasis on human needs and human development which is implemented through ODA policies. Japan also emphasizes Human security as preventing and resolving conflicts and human consequences in accordance with international standards on peace and cooperation. Thus, human security is a tool of foreign policy in dealing with international countries.

In Southeast Asia, Thailand is one of the countries that has a Ministry of Human Security. Thailand inherited the UNDP's view on human security in terms of "freedom from the fear, freedom from deprivation" and initiatives of human securities in developed countries. As a result, after the 1998 ASEAN Ministerial Meeting, Thailand proposed to establish the Committee on human security in the region with the aim of improving unemployment, poverty alleviation, lack of a safe social network, and well-being. Thailand also joins human security networks along with many countries in the world as well.

In sum, the approach to human security is gradually developing by international forums, organizations, different scholars from many countries, and so on. On one hand, studies have gradually built a theoretical foundation on human security such as concepts, structure, main dimensions, etc, other studies also have analyzed human security practices in specific countries, thereby drawing valuable lessons for other issues regarding human security. On the other hand, the debate on human security has been overlapped and has not reached a high agreement among researchers. In addition, research on human security is still integrated into different fields. However, these studies also show that the approach to human security through studies in countries is correct, suitable to the specific conditions of each country, each region in dealing with risks and challenges.

\section{Human Security in Vietnam}

Vietnam is being a nation with "vulnerable" and extremely "sensitive" to geopolitical changes, population structure, territory, social upheaval, and natural disasters. Vietnam has advantages of embracing the sea, is the gateway of Southeast Asian countries and China, the intersection of the maritime silk route, the flows of culture and civilization... But Vietnam is also the destination of dominated purposes and seeking influence by other countries. Vietnam is suffering from storms, floods, and epidemics that threaten human security.

In the Declaration of Independence that gave birth to Vietnam in 1945, Uncle Ho also emphasized that "Every human being is born with the right to life, freedom and the right to referendum happiness". Although Uncle Ho's Declaration did not mention the concept of human security, meaning is people freedom from deprivation, freedom from fear, freedom from wanting to live a life of dignity.

Since the implementation of the Doi Moi policy in 1986, Vietnam has achieved many great achievements in economic and political stability, and the people's cultural and spiritual life has improved. These successes contribute to national security, social order, and safety, that is, to human security.

However, besides the achievements, Vietnam faces problems related to territorial security. In addition, anti-corruption has long been considered by the Party and State of Vietnam as an existential threat to the existence of the country and cause dangers to national security and political security. The crimes have been increasing and complicated developments related to human security such as health, dignity, honor, and high-tech crimes; increased tendency to violence; threats from the environment such as natural disasters, floods, droughts, sea-level rise, water pollution, air pollution, garbage, residual chemicals which are causing many diseases to people and health community; employment problems, unemployment, imbalance in economic development, labor safety, traffic safety, community security and so on. Most recently, the outbreak of Covid-19 has threats to human security, so it is raising many challenges in ensuring human security in the current new situation.

If before 2016, the concept of human security did not appear in government documents. After 2016, together with the Resolution of the 12th Party Congress, one of the six key tasks of Vietnam was identified: "ensure social security, human security associated with social security", the Resolution The XIII Congress, 2021 of the Party has further emphasized: "Human security is the center to ensure political and social development". In addition, 
General To Lam, Politburo member, Minister of Public Security explain more: The Resolution of the 13th Party Congress puts the human factors and human security at the center of all activities. Human security is both a striving goal and a driving force for ensuring socio-political stability and building and developing a long and prosperous country (Tran Viet Ha, 2021). As a result, one can see from the Resolutions of the Congress that Vietnam has begun to have a renewal of thinking on industrial security compared to previous years.

Recently years, studies on human security were interested in by Vietnamese researchers and gained certain achievements. There are many scientific articles, international conference proceedings, which were published in both domestic and foreign journals, focusing on human securities issues, human securities dimensions in the reality of Vietnam. Specifically, Vietnam has hosted national and international workshops on human security by leading state agencies such as the Vietnam Academy of Social Sciences, People's Police Portal, Diplomatic Academy of Vietnam, so and so. In addition, the Vietnamese state has encouraged researchers, the Party's advisory agencies to carry out projects focus on concepts of human securities Those researches received funds from the government such as the project of authors Dang Xuan Thanh, Dao Minh Huong (2016), Vu Anh Ninh, (2014), Tran Viet Ha, (2020, 2021). There are increasing studies that strong analyze on Communist Party's view on human security (Nguyen Viet Thong, 2021) and show advantages and challenges of guarantee to the human securities of the Vietnam state (Nguyen Huy Phong, 2017), (Nguyen Huy Phong, Pham Van Nghia, 2016), Nguyen Duc Tuan (2020) analyze theories of Human Security of Communist Party of Vietnam the context of Covid-19 epidemic prevention.

There are studies which argue on concrete dimension of human securities such as health security issues such as Nguyễn Thị Liên Hương (2005, 2006, 2010), Phạm Thiên Hương (2010), Dao Minh Huong (2019); food security Nguyễn Sinh Cúc (2000), Trần Nguyễn Mỹ Linh (2010), Trần Đức Viên (2011); environment security in the context of climate change (Nguyễn Ngọc Sinh và Nguyễn Đình Hòe , 2012), Đào Minh Hương (2010, 2011, 2012). Other studies look at corruption as a human security problem ( Nguyen Thanh Nhan (2007), Nguyen Duy Dung (2008), or illegal timber trade also look at from Human Security perspective, ( Cao Ngọc Anh , 2016).

In general, human securities have been studied by scholars but if compared with other sciences with a long history, the subject of human securities in Vietnam has been started later and less paid attention by researchers. Scientists still consider human security theories like separate pieces in a jigsaw puzzle, although these pieces have been clearly identified, they still cannot be put together (Lan Dung Pham, 2018). Therefore, it can be seen that researches on human security in Vietnam still has many limitations and gaps as follows:

Firstly, there has still no official field studying human security, thus, it is due to overlapping and heterogeneity among Vietnamese scholars about human security. Moreover, researchers found that human security includes threatening to Vietnamese society, but there has been no deep and specific study to classify the risks and threats to Vietnamese society.

Secondly, researchers are interested in human security issues but there is not any study using qualitative and quantitative methodologies to survey human security in practice.

Thirdly, Vietnam in the era of the industrial revolution 4.0, as well as the impact of the Covid-19 pandemic, but studies are still less focused on implementation conditions to guarantee human security according to current situation.

Fourthly, Vietnam is a multi-ethnic country, ethnic minority people are always vulnerable groups and be a threat to human security. In fact, there are not any studies assessing negative impacts, identifying threatening issues, forecasting trends and challenges of human security at the ethnic minority community

Fifthly, although Vietnam has international cooperation programs to deal with human security in the region Vietnam only focuses on establishing soft mechanisms, declarations, dialogues, exchanges, etc. Especially, there has been no research at the international level related to human security, although the security in The South China Sea is currently a dilemma that needs to be coordinated by many different countries in the region.

\section{Recommendations for Vietnam Studying in Human Security}

All in all, based on researches and approaches on human security, some recommendations on learned lessons for Vietnam, as follows:

Firstly, Vietnam needs inheritance and applying the UNDP's human security perspective, theories of scholars in the world and in the region, lessons learned from cross countries because all have earlier approached concepts of human security than Vietnam.

Secondly, Vietnam promotes the philosophy and ideology of the Party and State to guarantee human security in 
current situation, enhancing social security, implementing social justice, eradicating hunger and reducing poverty, developing social and economic security, culture, education, science, and technology, strengthening national defense and security, etc., for dealing with incoming threats to human security before the impact of pandemics and natural disasters. Studies on human security in Vietnam should be focused on a people-centered approach.

Thirdly, strengthening awareness and integrating human security in the development projects of the government. Vietnam should adopt the bilateral strategy in enhancing the human security sector, such as simultaneously receiving and training key staff, lecturers, researchers who are working at university, government agencies who go aboard especially developed countries to attend coursework on human studies. Vietnam should consider proposing the establishment of the Ministry of Human Securities same as Thailand or developing the department of human security in universities or institutes like some countries in the world.

Fourthly, Vietnam needs to develop comparative studies of human securities between countries in the region and across the world because those will open new approaches and provide a full understanding of both the lacking and advantage of government policies on human security in each country.

Fifthly, Vietnam should actively expand networks in the field of human security such as participating in forums at both domestic and international levels to achieve more common voices in overcoming challenges regarding threaten to human security.

Finally, Vietnam strengthens international cooperation policies on human securities, creating good conditions and connections for researchers to have better looking for impact and influences from outside rather than inside the country. Vietnamese scholars should be raising voices on human securities at domestic and international forums. Although human security has been less attention, it should be optimistic for a bright future in the science of human security. This is only a difficult period of time but it also is a chance to produce ideas, invest new ideologies, theories on human security.

\section{Conclusion}

All in all, from the above human security approaches, one can see human security is related to the survival of individuals, communities, even the world as well. On the one hand, human security has sometimes been neglected in policy, development programs. On the other hand, human security is also gradually affirming the correctness and effectiveness in implementing development strategy programs, poverty reduction, and ensuring peace across countries around the world. Good implementation of human security will contribute to national security and harmonious development for each country.

Rich learned lessons in both theories and practice on human securities across countries in the world have evidenced the effectiveness of the human security approach. Thus, it is time for Vietnam government agencies especially academy agencies should be considered in studying human securities as national strategies what the documents of Resolution The XIII Congress, 2021 of the Party have emphasized. More than that, it develops human securities research that will help Vietnam gain the SDG 16 - one of the key SDGs to promote human security in the 2030 Agenda.

\section{Acknowledgement}

This article is the product of the Project namely "Theoretical issues on human security in violence against children studies”. Agency in charge: Institute of Women Studies, Vietnam Women's Academy.

\section{References}

Alkire, S. (2003). A Conceptual Framework for Human Security. CRISE Queen Elizabeth House, University of Oxford.

Alkire, S. (2003). A Conceptual Framework for Human Security. Working Paper 2, CRISE Working Paper.

Anh, C. N. (2016). Timber trafficking and its impacts on Human security in Vietnam (Ph.d Thesis). University of Northumbria at Newcastle.

Annan, K. (2005). In larger freedom: Towards development, security, and human rights for all. Report of the Secretary General on the integrated and coordinated follow-up to the outcomes of the major United Nations conferences and summits in the economic, social, and related fields, 05-27078(E), New York, United Nations Press.

Anthony, \& Hassan, M. J. (Eds.). The Asia Pacific in the New Millenium: Political and Security Challenges. Kuala Lumpur: Institute of Strategic and International Studies.

Atanassova-Cornelis, E. (2005). Japan and the 'human security' debate: History, norms and pro-active foreign 
policy.

Communist Party of Vietnam. (2016). Document of the 12th National Congress of Deputies. National Political Publishing House Truth, Hanoi.

Communist Party of Vietnam. (2021). Document of the 12th National Congress of Deputies. National Political Publishing House Truth, Hanoi.

Ha, T. V. (2021). Human security in the context of globalization. National Political Publishing House.

Human Security and Agenda 2030.

King, G., \& Murray, C. (2001). Rethinking Human Security. Political Science Quarterly, 116(4), 585-610. https://doi.org/10.2307/798222

Paris, R. (2001). Human Security: Paradigm Shift or Hot Air? International Security, 26(2), 87-102. https://doi.org/10.1162/016228801753191141

Pham, L. D. (2019). The concept of Human Security in Vietnam, in book: Human Security Norms in East Asia (pp. 249-271). https://doi.org/10.1007/978-3-319-97247-3_12

Phong, N. H. (2017). Enforcement of Human Security: Achievements and Some Issues. Party History Review, (3).

Sam, A., \& Leaning, J. (2000). Human Security: A Case Analysis Framework in Transition and conflict. Working Paper Series, 11(8), September 2001, Harvard School of Public Health.

Suhrke, A. (1999). Human Security and the Interests of States. Security Dialogue, 30(3), 265-276. https://doi.org/10.1177/0967010699030003002

Tadjbakhsh, S. (2014). Human Security Twenty Years On. NOREF (Norwegian Peacebuilding Resource Center), June 26, 2014

Tadjbakhsh, S. C., \& Anuradha, M. (2007). Human Security: Concepts and Implications. New York: Routledge Advances in International Relationsand Global Politics. https://doi.org/10.4324/9780203965955

Thanh, D. X., \& Huong, D. T. M. (2017). Guarantee the human security in the context of globalization and international integration in Vietnam. Social Sciences Publishing House.

Thong, N. V. (2021). Human security in the document of the 13th Party Congress. Party History Review, (5).

Tuan, N. D. (2020). Some theories and practices to ensure human securities in the context of epidemic prevention Covid-19 in Vietnam. Vietnam Journal Human Right Law, (2).

UNDP report 1994, 1999, 2012, 2020.

UNFPA report 2020.

United Nations Development Program. (1994). Human Development Report. New York: Oxford University Press. https://doi.org/10.18356/87e94501-en

United Nations Development Program. (1998). Integrating Human Rights with sustainable human development. A UNDP Policy Document.

United Nations Development Program. (2000). Human Development Report. New York: Oxford University Press. https://doi.org/10.18356/b1ed65e9-en

United Nations News Press. (2001). Security Council Expresses Commitment to Pursue Conflict Prevention.

United Nations. (1999). Report of the Secretary-General to the Security Council on the Protection of Civilians in Armed Conflict. S/1999/957

World Bank. (2001a). World Development Report 2000/2001: Attacking Poverty. New York: Published for the World Bank by Oxford University Press.

World Bank. (2001b). Operational Policies 2.30 Development Cooperation and Conflict.

\section{Websites}

https://www.undp.org/content/undp/en/home/news-centre/speeches/2019/25th-anniversary-of-the-human-securit y-concept.html

https://www.un.org/humansecurity/agenda-2030/ 


\section{Copyrights}

Copyright for this article is retained by the author(s), with first publication rights granted to the journal.

This is an open-access article distributed under the terms and conditions of the Creative Commons Attribution license (http://creativecommons.org/licenses/by/4.0/). 